\title{
TINGKAT KETERJADIAN PENYAKIT LAYU STEWART PADA BENIH DAN RESPON BEBERAPA VARIETAS JAGUNG TERHADAP INFEKSI PANTOEA STEWARTII SUBSP. STEWARTII
}

\author{
Haliatur Rahma ${ }^{1}$, Meity S Sinaga ${ }^{1}, M^{2}$ emen Surahman², \& Giyanto ${ }^{1}$ \\ ${ }^{1}$ Departemen Proteksi Tanaman Fakultas Pertanian Institut Pertanian Bogor \\ ${ }^{2}$ Departemen Agronomi dan Hortikultura Fakultas Pertanian Institut Pertanian Bogor \\ Jl. Meranti Kampus IPB Darmaga, Bogor \\ E-mail: giyanto2@yahoo.com
}

\begin{abstract}
Disease incidence of Stewart's wilt on the seed and response of several maize varieties to Pantoea stewartii subp. stewartii. Stewart's wilt disease of maize is caused by Pantoea stewartii subsp. stewartii. This bacterium is seed-borne pathogens, when attacked maize caused yield lost 40-100\%. The objective of this research was to detemine the incidence level of stewart's wilt disease, growth of some varieties of maize and their response to stewart's wilt pathogens Pantoea stewartii subsp. stewartii. The research was conducted in the Laboratory of Bacteriology and Greenhouse Cikabayan IPB from November 2011 to March 2012. In experiment I, nineteen samples of maize were used for symptom test in the maize seedling stage, using Randomized Block Design with three replications. Experiment II used a Randomized Block Design with 2 factors: maize varieties ( 8 hybrids varieties, 3 open pollinated varieties, and 7 sweet corn varieties) and bacteria isolates (BGR 2, BGR 4, BGR 28, BGR7 and PSM 27), with three replications. The results showed in experiment I, the incidence of stewart's wilt disease ranged $2.00-15.33 \%$, germination and vigor index of maize seed were $68.00-95.33 \%$ and $55.33-90.67 \%$ respectively. While in experiment II, hybrid and open pollinated of maize varieties were resistant to moderately susceptible while all sweet corn varieties were susceptible to infection of Pantoea stewartii subsp. stewartii.
\end{abstract}

Key words: maize, Pantoea stewartii subsp. stewartii, seed-borne pathogens, stewart's wilt disease

\begin{abstract}
ABSTRAK
Tingkat kejadian penyakit layu Stewart pada benih dan respon beberapa varietas jagung terhadap infeksi Pantoea stewartii subsp. stewartii. Penyakit layu stewart merupakan penyakit pembuluh pada tanaman jagung yang disebabkan oleh bakteri Pantoea stewartii subsp. stewartii. Bakteri ini merupakan patogen tular benih, bila menyerang tanaman jagung bisa menurunkan hasil hingga mencapai $40-100 \%$. Penelitian ini bertujuan untuk mengamati kejadian penyakit layu stewart pada fase bibit, viabilitas benih dan respon beberapa varietas jagung terhadap inokulasi buatan Pantoea stewartii subsp. stewartii di rumah kaca. Penelitian dilakukan di Laboratorium Bakteriologi dan Rumah Kaca Cikabayan IPB dari bulan November 2011 sampai Maret 2012. Pada penelitian I, sembilan belas sampel benih diuji untuk melihat gejala layu stewart pada fase bibit. Penelitian dilakukan dengan Rancangan Acak Kelompok dengan tiga ulangan. Penelitian II, menggunakan Rancangan Acak Kelompok dengan 2 faktor, faktor 1 adalah varietas jagung ( 8 varietas hibrida, 3 varietas bersari bebas, dan 7 varietas jagung manis) dan faktor 2 adalah isolat bakteri (BGR 2, BGR 4, BGR7, BGR 28, dan PSM 27). Masing-masing perlakuan diulang 3 kali. Hasil penelitian I menunjukkan bahwa penyakit layu stewart telah ditemukan pada benih semua sampel benih jagung yang diuji, dengan kejadian penyakit 2,00 - 15,33\%, daya berkecambah benih antara 68,00 - 95,33\%, dan indeks vigor 55,33 $90,67 \%$. Varietas hibrida dan bersari bebas menunjukkan respon tahan hingga agak rentan, sedangkan semua varietas jagung manis menunjukkan respon rentan terhadap infeksi Pantoea stewartii subsp. stewarti.
\end{abstract}

Kata kunci: penyakit layu stewart, patogen tular benih, varietas jagung, Pantoea stewartii subsp. stewartii.

\section{PENDAHULUAN}

Jagung (Zea mays L.) menempati posisi penting dalam perekonomian nasional, karena merupakan sumber makanan pokok kedua setelah beras. Jagung juga mempunyai arti penting dalam pengembangan industri di Indonesia sebagai bahan baku untuk industri pangan maupun industri pakan ternak khususnya pakan ayam. Kebutuhan jagung terus meningkat seiring meningkatnya jumlah penduduk dan pakan ternak. Tahun 2008 terjadi peningkatan produksi jagung sebesar $22,8 \%$ dibandingkan tahun 2007 yaitu dari 13,3 juta ton menjadi 16,3 juta ton. Tetapi peningkatan tersebut lebih rendah pada tahun 2009 dan 2010 dengan produksi 
jagung hanya naik sebesar 8,04\% dan 2,19\% (BPS, 2010). Kendala tersebut terjadi karena kurangnya penggunaan benih bermutu sehingga mengakibatkan produktivitas rendah. Akibat rendahnya produktivitas jagung dalam negeri pemerintah melakukan impor untuk memenuhi kebutuhan konsumen. Tingkat kebutuhan impor jagung mencapai rata-rata 1,3 juta ton/tahun (BAPPENAS, 2006).

Importasi benih jagung ternyata berpotensi membawa penyakit tanaman yang terbawa melalui benih (seedborne pathogen). Salah satu penyakit penting pada jagung adalah layu stewart yang disebabkan oleh bakteri Pantoea stewartii subsp. stewartii. Berdasarkan Peraturan Menteri Pertanian Republik Indonesia Nomor 93/Permentan /Ot. 140/ 12/ 2011 tentang Jenis Organisme Pengganggu Tumbuhan Karantina (Permentan, 2011), bakteri P. stewartii subsp. stewartii termasuk Organisme Pengganggu Tanaman Karantina (OPTK) yang tergolong kategori A1. OPTK yang masuk dalam kategori A1 adalah organisme penyebab penyakit tanaman yang belum terdapat di wilayah Indonesia dan apabila ditemukan harus segera dimusnahkan. Penyakit ini telah ditemukan di Sumatera Barat dengan kejadian penyakit berkisar $1 \%-15 \%$. Gejala berupa klorosis pada permukaan daun, layu, dan kerdil (fase vegetatif) sedangkan pada tanaman dewasa bercak hijau kekuningan memanjang di sepanjang permukaan daun yang disertai dengan matinya jaringan (nekrosis) (Rahma \& Armansyah, 2008). Telah terdeteksinya penyakit layu stewart di beberapa lokasi di Sumatera Barat mengindikasikan bahwa benih yang digunakan terinfeksi oleh patogen penyebab layu stewart.

Penelitian ini bertujuan untuk mengetahui tingkat kejadian penyakit layu stewart pada fase bibit dan respon varietas jagung terhadap inokulasi buatan $P$. stewartii subsp. stewartii di rumah kaca.

\section{METODE PENELITIAN}

Tempat dan Waktu. Penelitian dilakukan di Laboratorium Bakteriologi Tumbuhan Departemen Proteksi Tanaman dan Rumah Kaca Cikabayan Institut Pertanian Bogor, mulai bulan November 2011 sampai dengan Maret 2012.

Tingkat Kejadian Penyakit Layu Stewart pada Benih Jagung. Penelitian menggunakan 19 sampel benih jagung yang beredar di pasaran. Rancangan penelitian menggunakan Rancangan Acak Kelompok satu faktor. Masing-masing perlakuan menggunakan 50 benih jagung dengan 3 kali ulangan. Pengujian menggunakan wadah plastik ukuran 40 x $30 \mathrm{~cm}$ yang berisi media tanam berupa campuran tanah dan pupuk kandang sapi steril dengan perbandingan $1: 1(\mathrm{v} / \mathrm{v})$. Pengamatan dilakukan terhadap:

a) kejadian penyakit layu stewart $(\mathrm{KjP})$,

$$
\mathrm{KjP}=\frac{\text { Jumlah tamman bergejala }}{\text { Jumlah tamman yang diamati }} \times 100 \%
$$

b) daya berkecambah (DB) dihitung berdasarkan Sadjad et al. 1999) dengan menghitung persentase kecambah normal $(\mathrm{KN})$ hitungan pertama yaitu 5 hari setelah tanam (HST) dan kedua (7 HST),

$\mathrm{DB}=\frac{\sum \mathrm{KN} \text { hitungan } \mathrm{I}+\sum \mathrm{KN} \text { hitungan II }}{\sum \text { benih yang ditanam }} \times 100 \%$

c) vigor benih. Indeks vigor (IV) dihitung dari persentase kecambah normal pada pengamatan hitungan ke-1(5 HST).

$$
\mathrm{IV}=\frac{\sum \mathrm{KN} \text { hitungan I }}{\sum \text { benih yang ditanam }} \times 100 \%
$$

\section{Respon Ketahanan beberapa Varietas Jagung terhadap Pantoea stewartii subsp. stewartii.} Rancangan penelitian menggunakan Rancangan Faktorial dalam Acak Kelompok dengan 2 faktor yaitu varietas jagung dan isolat bakteri. Faktor varietas terdiri atas 12 varietas jagung (Bima 5, Bisi 16, Dekalb 979, Pioneer 21, Arjuna, Lamuru, Srikandi Putih, Virginia, Bonanza, SD 3, Hawai Super Sweet Corn, dan Soon Huat) dan faktor isolat bakteri $P$. stewartii subsp. stewartii yang terdiri atas 5 isolat (BGR2, BGR4, BGR28, BGR70, PSM27). Benih jagung ditanam pada polybag volume $10 \mathrm{~kg}$ dengan media tanah dan kompos (3:1), benih ditanam 3 butir/polybag, inokulasi patogen dilakukan pada saat bibit berumur 8 hari (Coplin et al. 2002). Isolat bakteri dibiakkan pada media Luria Bertani (Tryptone $10 \mathrm{~g}, \mathrm{NaCl}$ 5,0 g, Yeast Extract 5,0 g, Agar $15,0 \mathrm{~g}$, akuades $1 \mathrm{~L})$, kemudian diinkubasi 24 jam di atas rotary shaker (100 rpm) pada suhu ruang. Suspensi bakteri kemudian diencerkan dengan akuades steril dan diukur tingkat kekeruhannya menggunakan spektrofotometer pada panjang gelombang $600 \mathrm{~nm}$ dengan OD 0,4 yang diperkirakan mengandung sel bakteri $10^{7}-10^{8} \mathrm{sel} \mathrm{ml}^{-1}$. Inokulasi dilakukan dengan menyuntikkan suspensi bakteri pada pseudostem bibit jagung. Kontrol negatif diinokulasi menggunakan 
akuades steril. Setelah inokulasi, tanaman ditutup dengan plastik bening yang bertujuan untuk menjaga kelembaban lingkungan mikro bagi perkembangan sel bakteri. Masing-masing perlakuan diulang 3 kali. Peubah yang diamati adalah (a) periode laten, diamati setelah munculnya gejala (b) keparahan penyakit dan respon tanaman ditentukan berdasarkan metode Suparyono \& Pataky (2004) yang telah dimodifikasi, kriteria serangan pada Tabel 1. Untuk menghitung keparahan penyakit (KpP) layu stewart digunakan rumus sebagai berikut:

$$
\mathrm{KpP}=\frac{\sum \mathrm{n}_{\mathrm{i}} \mathrm{x} \mathrm{v}_{\mathrm{i}}}{\mathrm{N} \times \mathrm{V}} \times 100 \%
$$

keterangan:

$\mathrm{KpP}=$ persentase keparahan penyakit,

$\mathrm{n}_{\mathrm{i}}=$ jumlah tanaman bergejala layu stewart,

$\mathrm{v}_{\mathrm{i}}=$ nilai skala dari setiap kategori serangan layu stewart,

$\mathrm{N}=$ jumlah tanaman yang diamati, dan

$\mathrm{V}=$ nilai skala tertinggi dari kategori serangan.

Laju perkembangan penyakit (r) dihitung berdasarkan pada keparahan penyakit tanaman menggunakan rumus van der Plank (1963):

$$
\mathrm{r}=\frac{2.3}{\mathrm{t}_{2}-\mathrm{t}_{1}}\left\{\left(\log \mathrm{e} \frac{\mathrm{X}_{2}}{1-\mathrm{X}_{2}}\right)-\left(\log \mathrm{e} \frac{\mathrm{X}_{1}}{1-\mathrm{X}_{1}}\right)\right\}
$$

keterangan:

$\mathrm{t}_{2}-\mathrm{t}_{1}=$ selang waktu pengamatan (pengamatan ke-2 pengamatan ke-1),

$\mathrm{X}_{1}=$ keparahan penyakit pada pengamatan ke-1, dan $\mathrm{X}_{2}=$ keparahan penyakit pada pengamatan ke- 2 .

Pengaruh perlakuan terhadap peubah yang diamati dianalisis ragam menggunakan program Statistical Analysis System (SAS versi 9.1.3). Selanjutnya tiap perlakuan yang berpengaruh nyata dilakukan uji lanjut selang ganda Duncan pada taraf nyata $5 \%(P=0,05)$.

\section{HASIL DAN PEMBAHASAN}

Tingkat Kejadian Penyakit Layu Stewart pada Benih Jagung. Kejadian penyakit layu stewart pada sampel benih jagung berkisar antara $2,00-15,33 \%$, daya berkecambah 68,00-95,33\%, dan indeks vigor antara $55,33-90,67 \%$ (Tabel 2). Gejala penyakit layu stewart muncul ketika benih yang berkecambah normal telah berumur sekitar 1 minggu dan memiliki 2 - 3 helai daun. Gejala penyakit layu stewart pada bibit berupa layu pada daun dengan adanya bercak memanjang kebasahan (water soaking) disertai bercak kuning kehijauan di sepanjang pertulangan daun serta tanaman yang tumbuh ada yang layu dan kerdil. Gejala layu pada bibit dimulai dari bagian ujung daun kemudian berkembang ke seluruh bagian tanaman, bibit yang bergejala layu pada akhirnya mati. Menurut Thomas (2002), gejala layu stewart muncul pada fase bibit berupa garis hijau pucat kekuningan pada permukaan daun, layu dan kerdil pada saat pertumbuhan $2-5$ helai daun.

Ditemukannya gejala penyakit layu stewart pada cuplikan sampel benih jagung yang diuji menunjukkan bahwa benih ini telah terinfeksi Pantoea stewartii subsp. stewartii. Keberadaan patogen ini pada benih jagung perlu diwaspadai karena status penyakit layu stewart dan keberadaan bakteri Pantoea stewartii subsp. stewartii masih merupakan OPTK A1 (Permentan, 2011). Penyakit layu stewart merupakan penyakit endemik pada tanaman jagung di Amerika Serikat yang kemudian menyebar ke benua Eropa dan Asia seperti Thailand dan Vietnam (Giester \& Rees, 2004).

Ditemukannya gejala penyakit layu stewart pada sampel benih jagung yang diuji diduga merupakan salah satu dampak dari impor benih. Benih yang terinfeksi patogen penyebab layu stewart apabila ditanam dapat menyebabkan terjadinya penurunan hasil produksi mencapai 40-100\%. Menurut Neergaard (1977), uji gejala pada bibit merupakan salah satu cara deteksi patogen tular benih dengan mengamati perkembangan

Tabel 1. Kriteria penilaian keparahan penyakit dan respon tanaman jagung terhadap infeksi Pantoea stewartii subsp. stewartii

\begin{tabular}{cll}
\hline Skala & \multicolumn{1}{c}{ Keparahan Penyakit } & \multicolumn{1}{c}{ Respon Tanaman } \\
\hline 0 & Tidak ada gejala & Tahan (T) \\
1 & water-soaking, pada bagian yang diinokulasi $(0 \%-20 \%)$ & Tahan (T) \\
2 & water soaking, klorosis dan nekrosis $(21 \%-40 \%)$ & Agak Tahan (AT) \\
3 & Water soaking, klorosis dan nekrosis dan kerdil atau layu $(41 \%-60 \%)$ & Agak Rentan (AR) \\
4 & Kerdil atau layu 61\% - 100\% & Rentan (R) \\
\hline
\end{tabular}


Tabel 2. Kejadian penyakit layu stewart, daya berkecambah dan indeks vigor benih beberapa varietas jagung

\begin{tabular}{cccc}
\hline Kode sampel & Kejadian penyakit $(\%)$ & Daya berkecambah $(\%)$ & Indeks vigor \\
\hline BJ 8 & $15,33 \mathrm{a}^{*}$ & $68,00 \mathrm{~d}$ & $55,33 \mathrm{f}$ \\
BJ 9 & $14,67 \mathrm{a}$ & $86,67 \mathrm{bc}$ & $74,00 \mathrm{cde}$ \\
BJ 11 & $13,33 \mathrm{ab}$ & $81,33 \mathrm{c}$ & $71,33 \mathrm{de}$ \\
BJ 12 & $10,00 \mathrm{bc}$ & $88,00 \mathrm{abc}$ & $68,00 \mathrm{e}$ \\
BJ 13 & $8,67 \mathrm{~cd}$ & $87,33 \mathrm{abc}$ & $69,33 \mathrm{de}$ \\
BJ 17 & $7,33 \mathrm{cde}$ & $88,00 \mathrm{abc}$ & $79,33 \mathrm{bcd}$ \\
BJ 10 & $7,33 \mathrm{cde}$ & $92,00 \mathrm{ab}$ & $89,33 \mathrm{ab}$ \\
BJ 16 & $6,67 \mathrm{cdef}$ & $89,33 \mathrm{ab}$ & $73,33 \mathrm{cde}$ \\
BJ 2 & $6,67 \mathrm{cdef}$ & $93,33 \mathrm{ab}$ & $89,33 \mathrm{ab}$ \\
BJ 4 & $6,67 \mathrm{cdef}$ & $94,00 \mathrm{ab}$ & $84,67 \mathrm{ab}$ \\
BJ 1 & $5,33 \mathrm{cdef}$ & $91,33 \mathrm{ab}$ & $82,67 \mathrm{abc}$ \\
BJ 14 & $4,67 \mathrm{cdef}$ & $90,00 \mathrm{ab}$ & $73,33 \mathrm{cde}$ \\
BJ 7 & 4,67 def & $93,33 \mathrm{ab}$ & $88,67 \mathrm{ab}$ \\
BJ 18 & $4,00 \mathrm{def}$ & $87,33 \mathrm{abc}$ & $85,33 \mathrm{ab}$ \\
BJ 19 & 4,00 def & $88,00 \mathrm{abc}$ & $70,67 \mathrm{de}$ \\
BJ 3 & 4,00 def & $91,33 \mathrm{ab}$ & $74,00 \mathrm{cde}$ \\
BJ 15 & $4,00 \mathrm{def}$ & $91,33 \mathrm{ab}$ & $84,00 \mathrm{ab}$ \\
BJ 6 & 3.33 ef & $94,67 \mathrm{ab}$ & $90,67 \mathrm{a}$ \\
BJ 5 & $2,00 \mathrm{f}$ & $95,33 \mathrm{a}$ & $88,00 \mathrm{ab}$ \\
\hline
\end{tabular}

Angka-angka pada kolom yang sama diikuti huruf yang sama menunjukkan hasil yang tidak berbeda nyata pada uji Duncan 5\%.

bibit pada kondisi lingkungan yang cocok untuk perkembangan gejala penyakit. Dari hasil uji ini dapat diramalkan besarnya infeksi di lapangan mulai dari bibit yag terserang menjadi tanaman yang sakit. Resiko penularan patogen penyebab layu stewart melalui benih sangat penting untuk diperhatikan terutama dalam impor benih. Lebih dari 50 negara melarang impor benih jagung dari Amerika Serikat (daerah endemik) layu stewart, kecuali untuk benih-benih yang telah bersertifikat dan bebas dari patogen penyebab layu stewart (Thomas, 2002).

Hasil penelitian ini menunjukkan tidak ada kaitan antara persentase kejadian penyakit layu stewart dengan daya berkecambah serta indeks vigor benih. Kecuali pada sampel BJ 6 yang menunjukkan persentase kejadian penyakit yang tinggi diikuti dengan rendahnya daya berkecambah serta indeks vigor benih. Hal ini juga sangat dipengaruhi oleh lama waktu dan kondisi penyimpanan benih. Benih jagung komersil terutama yang diimpor, dalam pendistribusian sampai ke konsumen memerlukan waktu yang lama sehingga akan mempengaruhi daya berkecambah dan indeks vigor benih. Menurut Ilyas (2010) beberapa faktor yang mempengaruhi mutu benih adalah viabilitas yang mencakup daya berkecambah dan indeks vigor serta bebas dari patogen tular benih. Menurut Shah et al. (2002) benih dengan daya berkecambah yang sama tetapi dengan vigor yang berbeda akan menunjukkan variasi pertumbuhan yang berbeda nyata pada kondisi lingkungan yang berbeda.

Respon Ketahanan beberapa Varietas Jagung terhadap Pantoea stewartii subsp. stewartii. Tabel 3 menunjukkan perbedaan periode laten, keparahan penyakit dan laju infeksi penyakit layu stewart pada berbagai varietas jagung. Periode laten isolat Pantoea stewartii subsp. stewartii berkisar $3-6$ hari setelah inokulasi. Periode laten tercepat umumnya ditunjukkan oleh semua isolat Pantoea stewartii subsp. stewartii yang diinokulasi pada varietas jagung manis. Isolat BGR70 menunjukkan periode laten yang lebih lama pada varietas hibrida maupun bersari bebas yaitu $4-6$ hari setelah inokulasi, sementara empat isolat lainnya menunjukkan periode laten 3-4 setelah inokulasi pada varietas hibrida dan bersari bebas.

Keparahan penyakit layu stewart yang pada beberapa varietas jagung berkisar 14,58\% - 95,83\%. Laju perkembangan penyakit berkisar $0,06-0,34$ unit/ hari. Hasil penelitian ini menunjukkan bahwa keparahan penyakit layu stewart berkorelasi positif dengan laju 
Tabel 3. Tingkat keparahan penyakit layu stewart pada beberapa verietas jagung yang diinokulasi dengan beberapa isolat Pantoea stewarii subsp. stewartii

\begin{tabular}{|c|c|c|c|c|c|c|c|c|c|c|c|c|c|c|c|}
\hline \multirow{3}{*}{ Varietas } & \multicolumn{15}{|c|}{ Isolat bakteri } \\
\hline & \multicolumn{3}{|c|}{ BGR2 } & \multicolumn{3}{|c|}{ BGR4 } & \multicolumn{3}{|c|}{ BGR28 } & \multicolumn{3}{|c|}{ BGR70 } & \multicolumn{3}{|c|}{ PSM27 } \\
\hline & PL & $\mathrm{KpP}$ & $r$ & PL & $\mathrm{KpP}$ & $\mathrm{r}$ & PL & $\mathrm{KpP}$ & r & PL & $\mathrm{KpP}$ & $r$ & PL & $\mathrm{KpP}$ & $r$ \\
\hline \multicolumn{16}{|c|}{ Jagung Hibrida } \\
\hline Pioneer & 3,67 & 27,08 & 0,06 & 3,00 & 25,00 & 0,08 & 3,00 & 37,50 & 0,09 & 4,67 & 18,75 & 0,06 & 3,33 & 25,00 & 0,11 \\
\hline 21 & $\begin{array}{l}a b^{*} \\
A B C^{* *}\end{array}$ & & $\begin{array}{l}\mathrm{a} \\
\mathrm{B}\end{array}$ & $\begin{array}{l}\mathrm{a} \\
\mathrm{A}\end{array}$ & $\begin{array}{l}\mathrm{ab} \\
\mathrm{B}\end{array}$ & $\begin{array}{l}a b \\
B\end{array}$ & $\begin{array}{l}\mathrm{a} \\
\mathrm{A}\end{array}$ & $\begin{array}{l}\text { ab } \\
\mathrm{C}\end{array}$ & $\begin{array}{l}\mathrm{a} \\
\mathrm{B}\end{array}$ & $\begin{array}{l}\text { bcd } \\
A B C\end{array}$ & $\begin{array}{l}\mathrm{a} \\
\mathrm{B}\end{array}$ & $\begin{array}{l}\mathrm{a} \\
\mathrm{B}\end{array}$ & $\begin{array}{l}a b \\
A B\end{array}$ & $\begin{array}{l}\mathrm{a} \\
\mathrm{B}\end{array}$ & $\begin{array}{l}\mathrm{a} \\
\mathrm{B}\end{array}$ \\
\hline \multirow[t]{3}{*}{ Bima5 } & 4,00 & 31,25 & 0,06 & 3,00 & 22,92 & 0,07 & 3,00 & 56,25 & 0,23 & 5,00 & 16,67 & 0,05 & 3,00 & 56,25 & 0,18 \\
\hline & $a b$ & abc & $\mathrm{a}$ & a & $\mathrm{a}$ & $a b$ & a & $\mathrm{cd}$ & bc & bcde & $\mathrm{a}$ & $\mathrm{a}$ & a & & abcd \\
\hline & $\mathrm{AB}$ & B & B & A & B & B & A & $\mathrm{C}$ & C & $\mathrm{AB}$ & B & B & A & C & C \\
\hline \multirow[t]{3}{*}{ Bisi 16} & 4,00 & 39,58 & 0,08 & 3,30 & 25,00 & 0,10 & 3,30 & 60,42 & 0,13 & 5,30 & 16,67 & 0,12 & 3,67 & 45,83 & 0,18 \\
\hline & $\mathrm{ab}$ & abcd & $\mathrm{ab}$ & $\mathrm{ab}$ & $\mathrm{ab}$ & $\mathrm{ab}$ & $\mathrm{ab}$ & de & $\mathrm{a}$ & cde & $\mathrm{a}$ & $\mathrm{ab}$ & abc & bc & abcd \\
\hline & $\mathrm{ABC}$ & $\mathrm{CD}$ & B & A & BC & $\mathrm{BC}$ & A & $\mathrm{E}$ & $\mathrm{BC}$ & $\mathrm{C}$ & B & BC & $\mathrm{AB}$ & $\mathrm{DE}$ & C \\
\hline \multirow[t]{3}{*}{ Dekalb } & 4,33 & 45,83 & 0,08 & 5,00 & 29,17 & 0,09 & 4,00 & 47,92 & 0,16 & 5,00 & 45,83 & 0,12 & 4,00 & 37,50 & 0,15 \\
\hline & $\mathrm{ab}$ & abcd & $\mathrm{ab}$ & $\mathrm{d}$ & $\mathrm{ab}$ & $\mathrm{ab}$ & $\mathrm{ab}$ & bcd & $\mathrm{ab}$ & bcde & bcd & ab & bc & $\mathrm{ab}$ & abcd \\
\hline & $A B$ & $\mathrm{BC}$ & $\mathrm{B}$ & $\mathrm{AB}$ & B & B & A & $\mathrm{C}$ & B & $\mathrm{AB}$ & $\mathrm{BC}$ & B & A & B & B \\
\hline \multicolumn{16}{|c|}{ Jagung bersari bebas } \\
\hline \multirow[t]{3}{*}{ Lamuru } & 4,33 & 29,17 & 0,10 & 5,00 & 27,08 & 0,09 & 3,33 & 45,83 & 0,10 & 4,00 & 33,33 & 0,13 & 3,67 & 39,58 & 0,19 \\
\hline & $a b$ & $\mathrm{ab}$ & $\mathrm{ab}$ & d & ab & $\mathrm{ab}$ & ab & bcd & $\mathrm{a}$ & $\mathrm{ab}$ & $\mathrm{ab}$ & $\mathrm{ab}$ & $a b c$ & $\mathrm{ab}$ & abcd \\
\hline & BC & B & B & C & B & B & A & B & B & $\mathrm{ABC}$ & B & BC & $\mathrm{AB}$ & B & C \\
\hline \multirow[t]{3}{*}{ Srikandi } & 3,00 & 52,08 & 0,18 & 4,00 & 50,00 & 0,12 & 3,00 & 80,17 & 0,26 & 6,00 & 41,67 & 0,10 & 4,00 & 66,67 & 0,19 \\
\hline & $\mathrm{a}$ & de & cd & bcd & cd & $a b c$ & a & gh & de & $\mathrm{e}$ & bc & $\mathrm{ab}$ & bc & def & bcd \\
\hline & A & $\mathrm{BC}$ & $\mathrm{C}$ & B & BC & $\mathrm{BC}$ & A & $\mathrm{D}$ & $\mathrm{D}$ & $\mathrm{C}$ & $\mathrm{B}$ & B & B & $\mathrm{CB}$ & $\mathrm{CD}$ \\
\hline \multirow[t]{3}{*}{ Arjuna } & 4,00 & 50,00 & 0,08 & 3,67 & 25,00 & 0,06 & 3,33 & 33,33 & 0,10 & 4,30 & 14,58 & 0,06 & 3,67 & 31,25 & 1,33 \\
\hline & $a b$ & cde & $a b$ & $a b c$ & ab & a & $\mathrm{ab}$ & $\mathrm{ab}$ & a & bc & $\mathrm{a}$ & $\mathrm{a}$ & abc & $\mathrm{ab}$ & $a b$ \\
\hline & $\mathrm{AB}$ & $\mathrm{D}$ & $\mathrm{B}$ & $\mathrm{AB}$ & $\mathrm{BC}$ & B & A & CD & B & $\mathrm{AB}$ & B & B & $\mathrm{AB}$ & $\mathrm{BC}$ & B \\
\hline
\end{tabular}

$\mathrm{PL}=$ Periode Laten (hari), KpP = Keparahan Penyakit (\%), r = Laju Infeksi (unit/hari). Nilai PL, KpP, dan r merupakan hasil rata-rata dari 3 ulangan.

* Huruf kecil yang sama dibawah angka dalam satu kolom menujukkan tidak berbeda nyata berdasar uji Duncan pada taraf nyata 5\%.

** Huruf kapital yang sama dibawah angka dalam satu baris menujukkan tidak berbeda nyata berdasar uji Duncan pada taraf nyata 5\%. 


\begin{tabular}{|c|c|c|c|c|c|c|c|c|c|c|c|c|c|c|c|}
\hline \multirow{3}{*}{ Varietas } & \multicolumn{15}{|c|}{ Isolat bakteri } \\
\hline & \multicolumn{3}{|c|}{ BGR2 } & \multicolumn{3}{|c|}{ BGR4 } & \multicolumn{3}{|c|}{ BGR28 } & \multicolumn{3}{|c|}{ BGR70 } & \multicolumn{3}{|c|}{ PSM27 } \\
\hline & PL & KpP & $r$ & PL & KpP & $r$ & PL & KpP & $r$ & PL & $\mathrm{KpP}$ & $\mathrm{r}$ & PL & KрP & $\mathrm{r}$ \\
\hline \multicolumn{16}{|c|}{ Jagung Manis } \\
\hline \multirow[t]{3}{*}{ Virginia } & 3,00 & 79,17 & 0,27 & 3,00 & 66,67 & 0,23 & 3,00 & 97,92 & 0,34 & 3,00 & 50,00 & 0,17 & 3,00 & 68,33 & 0,24 \\
\hline & $a^{*}$ & $\mathrm{f}$ & ef & $\mathrm{a}$ & de & def & $\mathrm{a}$ & $\mathrm{h}$ & $\mathrm{e}$ & $\mathrm{a}$ & bcd & $\mathrm{b}$ & $\mathrm{a}$ & def & de \\
\hline & $A^{* *}$ & $\mathrm{C}$ & CD & A & $\mathrm{BC}$ & $\mathrm{BC}$ & $\mathrm{A}$ & $\mathrm{D}$ & $\mathrm{D}$ & A & B & B & A & $\mathrm{C}$ & $\mathrm{BC}$ \\
\hline \multirow[t]{3}{*}{ Hawaii } & 3,00 & 72,92 & 0,27 & 3,00 & 87,50 & 0,29 & 3,00 & 85,42 & 0,27 & 3,30 & 58,33 & 0,16 & 3,00 & 72,92 & 0,21 \\
\hline & $\mathrm{a}$ & f & ef & $\mathrm{a}$ & fg & fg & $\mathrm{a}$ & gh & de & $\mathrm{a}$ & cde & $\mathrm{b}$ & $\mathrm{a}$ & efg & bcde \\
\hline & A & $\mathrm{BC}$ & $\mathrm{C}$ & A & $\mathrm{C}$ & $\mathrm{C}$ & A & $\mathrm{C}$ & $\mathrm{C}$ & A & B & B & A & $\mathrm{BC}$ & $\mathrm{BC}$ \\
\hline \multirow[t]{3}{*}{ S. Huat } & 3,00 & 85,42 & 0,33 & 3,00 & 87,50 & 0,33 & 3,00 & 81,25 & 0,33 & 3,00 & 72,92 & 0,29 & 3,00 & 83,33 & 0,29 \\
\hline & $\mathrm{a}$ & $\mathrm{f}$ & $\mathrm{f}$ & $\mathrm{a}$ & fg & g & $\mathrm{a}$ & gh & e & $\mathrm{a}$ & e & C & $\mathrm{a}$ & fg & ef \\
\hline & A & B & B & A & $\mathrm{B}$ & B & A & $\mathrm{B}$ & B & A & B & B & $\mathrm{A}$ & B & B \\
\hline \multirow[t]{3}{*}{ Bonanza } & 3,00 & 89,58 & 0,20 & 3,00 & 95,83 & 0,20 & 3,00 & 91,67 & 0,23 & 4,00 & 43,75 & 0,17 & 3,33 & 79,17 & 0,21 \\
\hline & $\mathrm{a}$ & $\mathrm{f}$ & de & $\mathrm{a}$ & g & cde & $\mathrm{a}$ & gh & bcd & $\mathrm{a}$ & bc & $\mathrm{ab}$ & $\mathrm{ab}$ & fg & bcde \\
\hline & A & $\mathrm{C}$ & $\mathrm{C}$ & A & $\mathrm{C}$ & $\mathrm{C}$ & A & $\mathrm{C}$ & $\mathrm{C}$ & $\mathrm{AB}$ & B & B & $\mathrm{AB}$ & $\mathrm{C}$ & $\mathrm{C}$ \\
\hline \multirow[t]{3}{*}{ SD 3} & 3,00 & 85,42 & 0,28 & 3,00 & 87,50 & 0,33 & 3,00 & 87,50 & 0,33 & 3,00 & 60,42 & 0,17 & 3,00 & 83,33 & 0,29 \\
\hline & $\mathrm{a}$ & $\mathrm{f}$ & ef & $\mathrm{a}$ & fg & g & $\mathrm{a}$ & gh & $\mathrm{e}$ & $\mathrm{a}$ & cde & b & $\mathrm{a}$ & fg & ef \\
\hline & A & $\mathrm{C}$ & $\mathrm{C}$ & A & $\mathrm{C}$ & $\mathrm{C}$ & A & $\mathrm{C}$ & $\mathrm{C}$ & A & B & B & A & $\mathrm{C}$ & $\mathrm{C}$ \\
\hline
\end{tabular}

$\mathrm{PL}=$ Periode Laten (hari), KpP = Keparahan Penyakit (\%), $\mathrm{r}=$ Laju Infeksi (unit/hari). Nilai PL, KpP, dan r merupakan hasil rata-rata dari 3 ulangan.

* Huruf kecil yang sama dibawah angka dalam satu kolom menujukkan tidak berbeda nyata berdasar uji Duncan pada taraf nyata 5\%.

** Huruf kapital yang sama dibawah angka dalam satu baris menujukkan tidak berbeda nyata berdasar uji Duncan pada taraf nyata 5\%. 
perkembangan penyakit namun berkorelasi negatif dengan periode laten. Kemampuan suatu isolat bakteri patogen dalam menimbulkan penyakit pada rentang waktu tertentu berkaitan dengan virulensi dari isolat bakteri tersebut. Data pada Tabel 3 menunjukkan bahwa semakin singkat periode laten maka semakin tinggi keparahan penyakit dan laju perkembangan penyakit. Lima isolat $P$. stewartii subsp. stewartii menunjukkan virulensi yang tinggi pada varietas jagung manis, sementara pada varietas hibrida dan bersari bebas menunjukkan variasi virulensi dari kelima isolat. Berdasarkan hasil penelitian ini isolat BGR28 merupakan isolat dengan periode laten paling cepat, keparahan penyakit serta laju perkembangan penyakit yang paling tinggi, sementara isolat BGR70 merupakan isolat yang menunjukkan periode laten yang paling lama, dengan keparahan penyakit serta laju perkembangan penyakit yang lebih rendah.

Kemampuan dari bakteri P. stewartii subsp. stewartiii menginfeksi tanaman juga dipengaruhi oleh respon tanaman inang, patogen yang virulen serta kondisi lingkungan yang mendukung terjadinya infeksi. Tinggi rendahnya persentase keparahan penyakit layu stewart ditentukan oleh gejala yang muncul pada tanaman. Apabila gejala bersifat lokal, maka persentase keparahan penyakit juga rendah, sebaliknya bila gejala bersifat sistemik (layu pada keseluruhan tanaman) persentase keparahan penyakit juga tinggi. Terjadinya variasi tanggapan tanaman inang terhadap patogen disebabkan oleh adanya perbedaan jumlah gen ketahanan yang dimiliki oleh masing-masing varietas (Agrios, 2005).

Kriteria respon tanaman jagung terhadap infeksi penyakit layu stewart ditampilkan pada Tabel 4 . Berdasarkan hasil penelitian terhadap tiga kelompok varietas jagung yang diuji, menunjukkan respon yang berbeda terhadap inokulasi 5 isolat $P$. stewartii subsp. stewartii. Jagung varietas hibrida Pioneer 21, Bima 5, Bisi 16 dan Dekalb 979 menunjukkan respon tahan (T) hingga agak rentan (AR) terhadap isolat BGR2, BGR4, BGR28, PSM27 dan menunjukkan respon tahan (T) hingga agak tahan (AT) terhadap isolat BGR70. Jagung varietas bersari bebas menunjukkan respon tahan $(\mathrm{T})$ hingga rentan (R), sementara seluruh varietas jagung manis menunjukkan respon agak rentan (AR) hingga rentan (R) terhadap infeksi 5 isolat $P$. stewartii subsp. stewartii. Bervariasinya tanggapan varietas jagung terhadap isolat yang berbeda menunjukkan bahwa ketahanan dari masing-masing varietas tidak bersifat spesifik. Menurut Agrios (2005), bila suatu varietas tanaman inang diinokulasi dengan beberapa isolat bakteri, maka tanaman inang akan memberikan respon yang berbeda terhadap masing-masing isolat, hal ini

Tabel 4. Respon beberapa varietas jagung terhadap infeksi Pantoea stewartii subsp. stewartii

\begin{tabular}{|c|c|c|c|c|c|c|}
\hline \multirow{2}{*}{ Varietas } & \multicolumn{5}{|c|}{ Respon tanaman jagung terhadap Pantoea stewartii subsp. stewartii } & \multirow{2}{*}{$\begin{array}{c}\text { Kejadian Penyakit } \\
(\%)\end{array}$} \\
\hline & BGR2 & BGR4 & BGR28 & BGR70 & PSM27 & \\
\hline \multicolumn{7}{|c|}{ Jagung Hibrida } \\
\hline Pioneer 21 & AT & AT & AT & $\mathrm{T}$ & AT & 100 \\
\hline Bima5 & AT & AT & AR & $\mathrm{T}$ & AR & 100 \\
\hline Bisi 16 & AT & AT & AR & $\mathrm{T}$ & AR & 100 \\
\hline Dekalb & AR & AT & $\mathrm{AR}$ & $\mathrm{AR}$ & AT & 100 \\
\hline \multicolumn{7}{|c|}{ Jagung Bersari Bebas } \\
\hline Lamuru & AT & AT & AR & AT & AT & 100 \\
\hline Srikandi & AR & AR & $\mathrm{R}$ & AT & $\mathrm{R}$ & 100 \\
\hline Arjuna & $\mathrm{AR}$ & AT & AT & $\mathrm{T}$ & AT & 100 \\
\hline \multicolumn{7}{|c|}{ Jagung Manis } \\
\hline Virginia & $\mathrm{R}$ & $\mathrm{R}$ & $\mathrm{R}$ & AR & $\mathrm{R}$ & 100 \\
\hline Hawaii & $\mathrm{R}$ & $\mathrm{R}$ & $\mathrm{R}$ & AR & $\mathrm{R}$ & 100 \\
\hline S. Huat & $\mathrm{R}$ & $\mathrm{R}$ & $\mathrm{R}$ & $\mathrm{R}$ & $\mathrm{R}$ & 100 \\
\hline Bonanza & $\mathrm{R}$ & $\mathrm{R}$ & $\mathrm{R}$ & AR & $\mathrm{R}$ & 100 \\
\hline SD 3 & $\mathrm{R}$ & $\mathrm{R}$ & $\mathrm{R}$ & $\mathrm{R}$ & $\mathrm{R}$ & 100 \\
\hline
\end{tabular}

$\mathrm{T}=$ Tahan, $\mathrm{AT}=$ Agak Tahan, $\mathrm{AR}=$ Agak Rentan, $\mathrm{R}=$ Rentan 
disebabkan varietas tersebut memiliki beberapa gen ketahanan yang berbeda yang bersifat khusus terhadap isolat tertentu. Menurut Suparyono \& Pataky (1989), jagung dikategorikan rentan apabila keparahan penyakit mencapai $40-100 \%$.

Menurut Pataky (2004), kelompok jagung hibrida gigi kuda (dent corn) merupakan varietas yang lebih tahan terhadap infeksi Pantoea stewartii subsp. stewartii bila dibandingkan dengan jagung manis. Freeman dan Pataky 2001) melaporkan bahwa tanaman jagung hibrida menunjukkan respon tahan sampai toleran terhadap penyakit layu stewart bila dibandingkan dengan jagung manis yang memiliki respon tahan sampai rentan. Menurut OEPP/EPPO (1987), bakteri P. stewartii subsp. stewartii merupakan patogen tular benih, tidak menyerang embrio sehingga benih jagung yang terinfeksi masih bisa berkecambah dengan normal. Bakteri $P$. stewartii subsp. stewartii ditemukan pada jagung manis maupun jagung hibrida tetapi dengan intensitas serangan yang berbeda, jagung manis tergolong rentan sementara jagung hibrida lebih tahan.

\section{SIMPULAN}

Analisis pada beberapa sampel benih jagung menunjukkan tingkat kejadian penyakit layu stewart dari $2,00-15,33 \%$, dengan daya berkecambah $68,00-$ $95,33 \%$, serta indeks vigor benih 55,33 - 90,67\% . Varietas hibrida dan bersari bebas menunjukkan respon tahan hingga agak rentan terhadap infeksi $P$. stewartii subsp. stewarti, sedangkan semua varietas jagung manis menunjukkan respon rentan.

\section{DAFTAR PUSTAKA}

Agrios GN. 2005. Plant Pathology. Ed-ke 5. San Diego. California. Academic Press.

Badan Pusat Statistik (BPS). 2010. Produksi dan produktivitas tanaman pangan. Dalam http:// www.bps.go.id [Diakses 11 Januari 2012].

BAPPENAS. 2006. Profil Pangan dan Pertanian 20032006. Direktorat Pangan dan Pertanian. Badan Perencanaan Nasional.

Coplin DL, Frederick RD, Majerczak DR, \& Haas ES 1986. Molecular Cloning of Viruslence Genes from Erwinia stewartii. J. of Bacteriol. 168(2):619-623.
Coplin DL, Majerczak DR, Zhang Y, Kim WS, Jock S, $\&$ Geider K. 2002. Identification of Pantoea stewartii subsp. stewartii by PCR and strain differentiation by PFGE. Plant Dis. 86:304-311.

Giester LJ \& Rees JM. 2004. Bacterial Diseases of Corn. Clay/Webster, St. Paul, MN, USA.

Ilyas S.2010. Ilmu dan Teknologi Benih Teori dan Hasil-hasil Penelitian. Institut Pertanian Bogor.

Permentan. 2011. Peraturan Menteri Pertanian Republik Indonesia Nomor 93/Permentan /Ot.140/12/2011 Tentang Jenis Organisme Pengganggu Tumbuhan Karantina.

Michener PM, Pataky JK, \& White DG. 2002. Transmission of Erwinia stewartii from Plants to Kernels and Reaction of Corn Hybrids to Stewart's Wilt. Plant Dis. 86:167-172.

Michener PM, Freeman ND, \& Pataky JK. 2003. Relationships between reaction of sweet corn hybrid to Stewart's wilt and incidence of systemic infection by Erwinia stewartii. Plant Dis. 87:223-228.

Neergaard P. 1977. Seed Pathology. MacMillan Press Ltd. London.

OEPP/EPPO. 1987. Pantoea stewartii subsp. stewartii. Data Sheets on Quarantine Pests, 1-4

OEPP/EPPO. 2006. Pantoea stewartii subsp. stewartii. Bulletin OEPP/EPPO Bulletin 36. 111-115.

Pataky JK, du Toit LJ, Revilla P, \& Tracy WF. 1998. Reactions of open-pollinated sweet corn cultivars to Stewart's wilt, common rust, northern leaf blight, and southern leaf blight. Plant Dis. 82:939944.

Pataky JK. 2004. Stewart's wilt of corn. The Plant Health Instructor. DOI:10.1094/PHI-I-2004-0113-01.

Rahma H \& Armansyah. 2008. Penyebaran Penyakit Stewart oleh Bakteri Pantoea stewartii Sebagai Penyakit Baru pada Tanaman Jagung (Zea Mays) Studi Kasus di Sumatera Barat. Penelitian Dosen Muda. DP2M DIKTI No 005/SP2H/PP/DP2M/ III/2008. 2008.

Sadjad S, Murniati E, \& Ilyas S. 1999. Parameter Pengujian Vigor Benih. Dari Komparatif ke Simulatif. Jakarta:Grasindo. 
Shah FS, Watson CE, \& Cabrera ER. 2002. Seed Vigor Testing of Subtropical Corn Hybrids. Research Report. Vol. 23, No. 2. Mississippi Agricultural $\&$ Forestry Experiment Station.
Thomas AZ. 2002. Stewart's Bacterial Wilt-Still a Problem After 107 Years. Department of Plant Pathology Cornell Universityu Ithaca, NY 14853.

van Der Plank JE. 1963. Plant Diseases: Epidemics and Control. Academic Press. New York. 